\title{
Behandling ved livets slutt - legen har nøkkelposisjonen
}

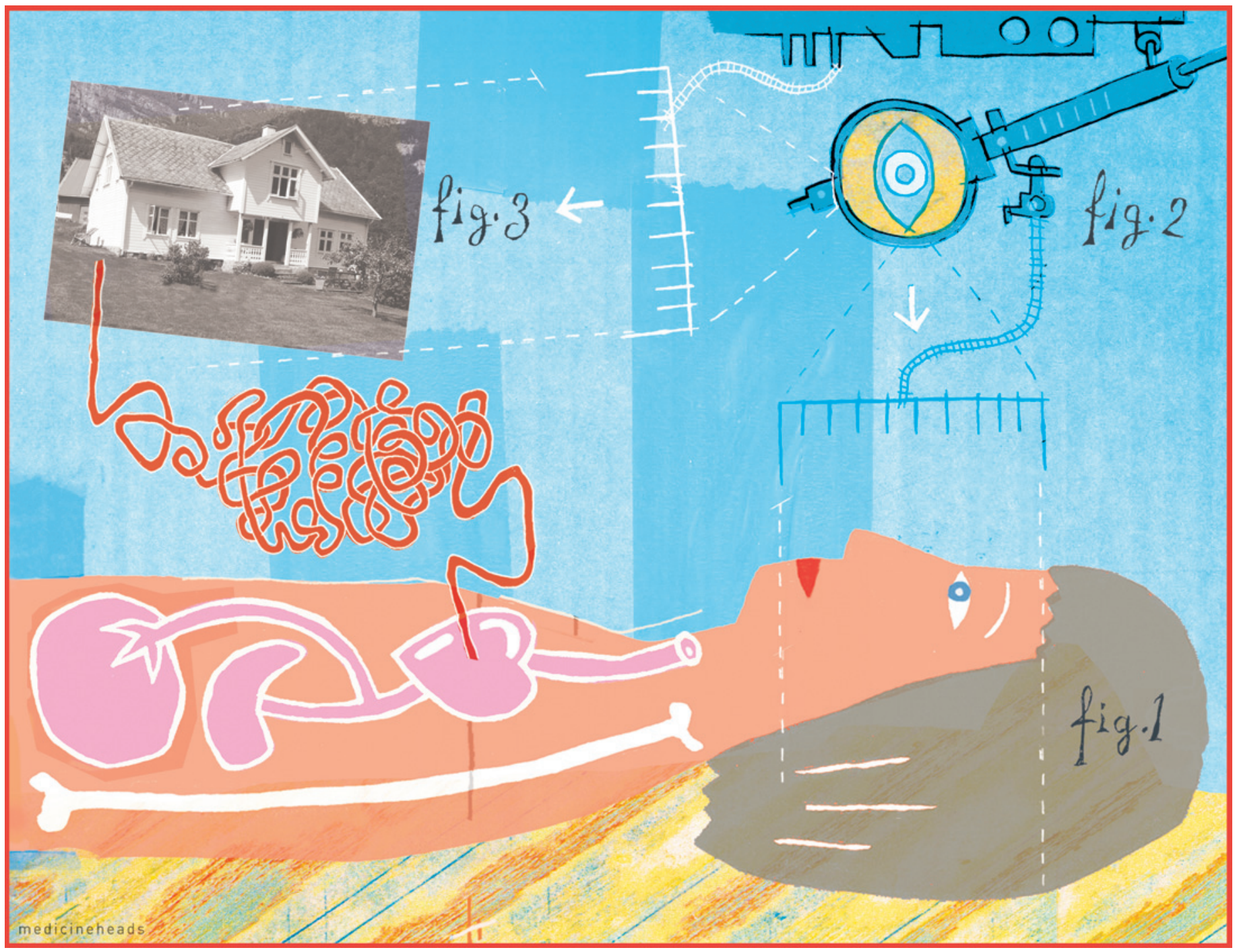

I 2001 etablerte Legeforeningen et utvalg for å drøfte legenes utfordringer i møte med eldrebølgen. Utvalgets anbefalinger ble utgitt med den treffende tittelen: Når du blir gammel og ingen vil ha deg (1). Det var et visjonært dokument, fordi mer enn ti år senere er kompetent behandling og omsorg for de eldre ikke en selvfølge tvert imot. Hvordan kan vi sikre de sårbare gamle en verdig siste levetid? Spørsmålet er fremdeles et aktuelt tema i fagmiljøene, i samfunnsdebatten og i politikken. Storting og Regjering har kommet med viktige føringer: verdighetsgarantien, demensplan og nå sist samhandlingsreformen.

En hovedkritikk av eldreomsorgen er at legenes rolle er diffus og at de ofte er fraværende. Det kan synes som om livets siste fase er en oppgave for pleiepersonalet. Men det er legene som skal sikre de sårbare gamle kompetanse og kvalitet når det gjelder medisinsk utredning, behandling, kommunikasjon og etiske retningslinjer i deres siste levetid. I 2010 døde $35 \%$ på sykehus, $44 \%$ i sykehjem, og $15 \%$ hjemme (2). Antallet dødsfall i sykehjem er i Norge det høyeste i verden. På våre sykehus er det en lege for 1,3 pasienter, i sykehjem ett legeårsverk for 130 pasienter (2). Er pasientene i sykehjem 100 ganger friskere enn pasientene på sykehus?

Samhandlingsreformen vil medføre at et større antall sårbare eldre tidligere blir utskrevet fra sykehus. Reformens konsekvens vil raskt kunne bli en omfattende diskriminering av pasientene, når de med tallrike sykdommer og enda flere medikamenter blir utskrevet til sykehjem eller hjemmet, uten sikret kompetent legeoppfølging. 
For hundre år siden døde det store flertallet hjemme. Liket var $i$ hjemmet til begravelsen. Alle familier hadde erfaring med dødsfall i hjemmet. Nå har døden flyttet inn på institusjon. I dag opplever familiene sjelden at farmor eller farfar får omsorg ved livets slutt hjemme. Vi har tatt livet av døden. Håndverket, omsorgen for den døende og de døde er overtatt av fagpersonalet. Dette er i våre øyne den største samfunnsendring av alle i de siste hundre år.

Behandlingen bør tilrettelegges slik at den siste levetid blir livets høydepunkt. Våre erfaringer viser at dette er mulig. Men noen grunnleggende forutsetninger må oppfylles.

Den ene forutsetningen er personalressurser. Når de skrøpelige gamle blir utskrevet fra sykehus, til sykehjem eller hjemmet, er de ikke bare en pleieutfordring. Pasientene må bli møtt med solid medisinsk kompetanse. Legetimene i sykehjem bør mer enn fordobles. Fastlegene må få premisser som belønner regelmessig legetilsyn i pasientenes siste levetid når vedkommende ønsker å dø hjemme.

Den andre forutsetningen er kompetanse. Den ansvarlige lege må ha bred fagkompetanse i alders- og sykehjemsmedisin og palliativ behandling ved livets slutt $(3,4)$. Når pasientens liv nærmer seg slutten, må det utarbeides og samtales om en palliativ plan (5). Et anerkjent oppfølgingsverktøy som «Liverpool care pathway» kan bidra til å sikre optimal behandling og pleie (6).

Den tredje forutsetningen er etisk kompetanse, som i teori og praksis sikrer grunnleggende forutsetninger for hvilken type behandling som bidrar til livskvalitet for de døende. En aktuell oversiktsartikkel fremhever personalets ansvar for vanskelige avgjørelser og understreker at pårørende bør beskyttes for umulige valg (7). Vi må være tydelige på når vi ikke skal behandle. Det må være klarhet rundt informert og formodet samtykke. Vi må beskytte døende pasienter mot meningsløs behandling og transport mellom hjemmet, sykehus og sykehjem (8).

Den fjerde forutsetningen er kommunikasjon, med gode, forberedende samtaler (5). Når det ikke lenger er realistisk at omfattende medisinsk behandling kan bidra til pasientens helse, levetid eller livskvalitet, må legen ta initiativ til gjentatte, åpne samtaler med pasient og pårørende, hvor vi tydelig formidler hva som ikke er mulig, og hva som er mulig. Forberedende samtaler om liv og død bør initieres på et tidlig tidspunkt, senest når pasientens forventede levetid er mindre enn seks måneder.

Den femte forutsetningen er en akademisk forankring. I alle helseregioner bør det ved universitetene etableres forsknings- og undervisningssentre for alders- og sykehjemsmedisin. Disse sentrene vil kunne bidra til ny kunnskap og innsikt og bedre planer for en optimal eldreomsorg, og for rekruttering av engasjerte og kompetente leger. Eldremedisinen fortjener omfattende medisinsk kompetanse og status, med en bred plass i medisinstudiet, forskning og etterutdanning.
Den sjette forutsetningen er vår private. Hvordan ser vi på vår egen siste levetid? Hvor og hvordan ønsker vi å dø? De fleste av oss ønsker å dø hjemme, omgitt av våre nærmeste. Men det vil kreve en tidlig planlegging med åpne samtaler før det er for sent.

Forbedring er på vei. Siden 2001 er det etablert et Forum for Sykehjemsmedisin, med årlige landskonferanser og deltakelse fra entusiastiske leger fra sykehjem og kommunal eldreomsorg. I samarbeid med Legeforeningen ble det nylig vedtatt et kompetanseområde i alders- og sykehjemsmedisin; en formalisert kompetansegivende etterutdanning for leger. Norsk forening for aldersog sykehjemsmedisin under Legeforeningens paraply vil snart bli etablert.

Vi leger har en nøkkelposisjon for å sikre kompetent behandling av de sårbare gamle og en god omsorg ved livets slutt. Dette legearbeidet medfører en uerstattelig berikelse for den døende pasient, for de pårørende og for legen selv.

\section{Bettina S. Husebø}

bettina.husebo@isf.uib.no

Institutt for samfunnsmedisinske fag

Universitetet i Bergen

\section{Stein Husebø}

Verdighetssenteret

c/o Bergen Røde Kors sykehjem

Bettina S. Husebø (f. 1959) er ph.d. og førsteamanuensis ved Institutt for samfunnsmedisinske fag, Universitetet i Bergen, og forsker ved Regionalt kompetansesenter for eldremedisin og samhandling (SESAM), Stavanger universitetssjukehus.

Forfatter har fylt ut ICMJE-skjemaet og oppgir ingen interessekonflikter

Stein Husebø (f. 1944) er leder og overlege ved Verdighetsenteret Omsorg for gamle ved Bergen Røde Kors sykehjem.

Forfatter har fylt ut ICMJE-skjemaet og oppgir ingen interessekonflikter.

Litteratur

1. Den norske legeforening. Når du blir gammel og ingen vil ha deg. Oslo: Den norske legeforening, 2001.

2. Statistisk sentralbyrå 2012. www ssb no.

3. Chen JH, Chan DCD, Kiely DK et al. Terminal trajectories of functional decline in the long-term care setting. J Gerontol A Biol Sci Med Sci 2007; 62: 531-6.

4. Husebø BS, Husebø SB. Sykehjemmene som arena for terminal omsorg hvordan giør vi det i praksis? Tidsskr Nor Lægeforen 2005; 125: 1352-4.

5. Husebo SB, Husebo BS. Palliativ plan - eldreomsorg. Nord Tidsskr Pall Med $2011 ; 28: 43-50$

6. Ellershaw J. Care of the dying: what a difference an LCP makes! Palliat Med 2007: 21: 365-8

7. Dening $\mathrm{KH}$, Jones L, Sampson EL. Advance care planning for people with dementia: a review. Int Psychogeriatr 2011; 23: 1535-51.

8. Graverholt B, Riise T, Jamtvedt $G$ et al. Acute hospital admissions among nursing home residents: a population-based observational study. BMC Health Serv Res 2011; 11: 126-33. 